\title{
Sonic hedgehog is a potent chemoattractant for human monocytes: diabetes mellitus inhibits Sonic hedgehog-induced monocyte chemotaxis
}

\author{
Marina Dunaeva $\cdot$ Stefan Voo • \\ Carolien van Oosterhoud $\cdot$ Johannes Waltenberger
}

Received: 5 January 2009/Revised: 29 June 2009/Accepted: 10 July 2009/Published online: 24 July 2009

(C) The Author(s) 2009. This article is published with open access at Springerlink.com

\begin{abstract}
The aim of the present study was to evaluate the expression of hedgehog $(\mathrm{Hh})$ signaling molecules and the chemotactic activity of Sonic hedgehog (Shh) in monocytes from control (CTR) and diabetic patients with or without coronary artery disease (CAD). Previously several studies demonstrated that exogenous administration of Shh can induce angiogenesis and accelerate repair of ischemic myocardium and skeletal muscles. Blood samples were collected from (1) CTR $(n=25)$; (2) patients with stable CAD without diabetes mellitus (CAD-DM, $n=10)$; and (3) with stable CAD with DM (CAD+DM, $n=15)$. Monocytes were isolated by Percoll gradient and subjected to PCR and chemotaxis analysis. Hh signaling molecules were expressed in human monocytes, and Shhinduced monocyte chemotaxis. Shh-stimulated migration of monocytes from CTR measured $172.5 \pm 90 \%$ and a maximal stimulation was observed at Shh concentration of $1 \mu \mathrm{g} / \mathrm{ml}$. However, Shh failed to induce migration of monocytes from CAD+DM $(94.3 \pm 27 \%, P<0.001$ vs. CTR). The impaired response to Shh was associated with strong transcriptional upregulation of the receptor Ptc, while expression of downstream molecules was not altered. Moreover, Ptc is strongly expressed in macrophages of human aortic atherosclerotic plaque. Thus, Shh is a potent chemoattractant for monocytes and it activates classical signaling pathways related to migration. The Shh signaling
\end{abstract}

M. Dunaeva $\cdot$ S. Voo $\cdot$ C. van Oosterhoud .

J. Waltenberger $(\square)$

Department of Cardiology, University Hospital of Maastricht, Cardiovascular Research Institute of Maastricht (CARIM),

P.Debyelaan 25, P.O. Box 5800,

6202 AZ Maastricht, The Netherlands

e-mail: j.waltenberger@mumc.nl was negatively affected by DM which might be involved in the pathogenesis of DM-related complications.

Keywords Monocytes $\cdot$ Hedgehog $\cdot$ Signal transduction · Chemotaxis $\cdot$ Atherosclerosis

\section{Introduction}

The Hedgehog (Hh) pathway is highly conserved in evolution and Hh proteins are essential for cell fate decisions during development and homeostasis of adult tissues. Three proteins compose the Hh family: Sonic (Shh), Indian (Ihh) and Desert (Dhh) hedgehogs. All Hh proteins bind to a surface receptor complex comprised of two transmembrane proteins Patched (Ptc), a receptor for Hh proteins and Smoothened (Smo), a signal transducer. It has been demonstrated that all Hh members Shh, Ihh and Dhh proteins bind the receptor Ptc with similar affinity, however, they vary with regard to their potency. The rank order of potency was generally $\mathrm{Shh} \geq \mathrm{Ihh} \geq \mathrm{Dhh}$ [27]. The $\mathrm{Hh}$ signal is then mediated by the Gli family transcription factors (Gli 1-3), which regulate the expression of different target genes [10].

There is increasing evidence for the role of $\mathrm{Hh}$ signaling in vascularization and neovascularization. Recently, it has been shown that activation of Hh signaling is critical for coronary development and sufficient to promote formation of coronary vessels in the embryonic and adult heart [13, $22,29]$. Shh gene therapy could promote both angiogenesis and arteriogenesis and protect from ischemic injury in rodent and large animal models [21]. However, the mechanism how Shh induces neovascularization is still unknown. It has been shown that blood circulating mononuclear cells play an important role in both artheriogenesis 
and angiogenesis [15, 32]. They adhere to the arterial wall, infiltrate and stimulate vessel growth in the ischemic tissue by the release of cytokines, growth factors and proteases. Several recent studies have suggested a role of $\mathrm{Hh}$ signaling in the control of motility and migration of multiple cell types. Hedgehog proteins act as a chemoattractant on isolated axons, guide neuronal migration during embryonic development [6], serves as an attractive cue to guide germ cell migration through the embryo to form primitive gonad in Drosophila [12], promote the migration of endothelial progenitor cells [1], rat activated pancreatic stellate cells [33], embryonic endothelial cells and fibroblasts [18] as well as optic nerve oligodendrocyte precursors [24]. However, nothing is known about migration control of immune cells by $\mathrm{Hh}$ proteins. Here, we tested the hypothesis whether Shh stimulates monocyte chemotaxis. Our results demonstrate that Shh is a potent chemoattractant for peripheral monocytes and it activates classical signaling pathways related to cellular migration such as G-proteins or PI3K. Moreover, we provide the first piece of evidence that pathological conditions such as diabetes mellitus (DM) significantly impair Shh-induced chemotaxis, which is accompanied by elevated expression levels of Ptc. Thus, these data indicate that the Hh signaling pathway (1) is involved in monocyte biology and (2) is negatively affected by the cardiovascular risk factor DM.

\section{Methods}

\section{Study population}

This study was performed with the approval of the medical ethics committee of the University Hospital of Maastricht (The Netherlands), and conforms to the principals outlined in the Declaration of Helsinki. All enrolled subjects gave their written informed consent. Three groups of subjects were studied: (1) Patients with stable coronary artery disease without diabetes mellitus (CAD-DM, $n=10)$. Stable $\mathrm{CAD}$ was defined as history of stable angina pectoris or history of PCI and/or CABG. Patients with acute myocardial infarction and/or recent surgical intervention (less then 6 months) were excluded. All patients had a recent coronary angiogram. (2) CAD patients with diabetes mellitus $(\mathrm{CAD}+\mathrm{DM}, n=15)$. The diagnosis of $\mathrm{DM}$ was verified by history of DM, elevated fasting glucose level and/or increased concentration of glycosylated $\mathrm{HbAl}_{\mathrm{c}}$. (3) Control subjects (CTR) without any history or clinical signs of
Table 1 Clinical characteristics of control subjects and patients

Results are expressed as the mean \pm SD. $P$ value indicated for $\mathrm{CAD}-\mathrm{DM}$ versus $\mathrm{CAD}+\mathrm{DM}$

$C A D$ Coronary artery disease, $D M$ type 2 diabetes mellitus, $A C E$ angiotensin converting enzyme, $A R B$ angiotensin receptor blockers, FPG fasting plasma glucose, $N D$ not determined, $O H D$ oral hypoglycemic drugs

\begin{tabular}{|c|c|c|c|c|}
\hline & $\mathrm{CTR}, n=25$ & CAD-DM, $n=10$ & $\mathrm{CAD}+\mathrm{DM}, n=15$ & $P$ value \\
\hline Age (years) & $59.9 \pm 12.7$ & $63.7 \pm 9.9$ & $66 \pm 11$ & 0.579 \\
\hline BMI & ND & $26.8 \pm 2$ & $26.3 \pm 5$ & \\
\hline Male gender, $n(\%)$ & $12(48)$ & $7(70)$ & $9(60)$ & 0.470 \\
\hline \multicolumn{5}{|l|}{ Cardiovascular risk factors } \\
\hline CAD history (years) & 0 & $10 \pm 8$ & $9 \pm 8$ & 0.578 \\
\hline Family history of CAD, $n(\%)$ & $11(44)$ & $7(70)$ & 7 (47) & 0.231 \\
\hline Hypertension, $n(\%)$ & $12(48)$ & $4(40)$ & $9(60)$ & 0.284 \\
\hline Smoking, $n(\%)$ & $6(24)$ & $3(30)$ & $6(40)$ & 0.607 \\
\hline Diabetes, $n(\%)$ & $0(0)$ & $0(0)$ & $15(100)$ & \\
\hline Duration of DM (years) & 0 & 0 & $8 \pm 7$ & \\
\hline Patients receiving insulin (\%) & 0 & 0 & 40 & \\
\hline Patients receiving OHD (\%) & 0 & 0 & 100 & \\
\hline FPG $(\mathrm{mmol} / \mathrm{l})$ & $5.5 \pm 0.7$ & $6.3 \pm 0.7$ & $8.3 \pm 4.6$ & 0.048 \\
\hline $\mathrm{HbA}_{1 \mathrm{c}}(\%)$ & ND & ND & $7.3 \pm 0.6$ & \\
\hline \multicolumn{5}{|l|}{ Laboratory parameters } \\
\hline Cholesterol, total $(\mathrm{mmol} / \mathrm{l})$ & $5.9 \pm 1.3$ & $4.4 \pm 0.8$ & $4.0 \pm 1.4$ & 0.283 \\
\hline LDL-cholesterol (mmol/l) & $4.0 \pm 1.2$ & $2.1 \pm 0.8$ & $2.1 \pm 0.9$ & 0.16 \\
\hline HDL-cholesterol (mmol/l) & $1.8 \pm 1.0$ & $1.2 \pm 0.6$ & $1.0 \pm 0.3$ & 0.127 \\
\hline Triglycerides (mmol/l) & $1.8 \pm 1.2$ & $1.8 \pm 0.4$ & $2.1 \pm 1.1$ & 0.638 \\
\hline \multicolumn{5}{|l|}{ Medication at admission } \\
\hline $\begin{array}{l}\text { Antiaggregatory therapy } \\
\text { (antiplatelet drugs) } n(\%)\end{array}$ & $11(44)$ & $7(70)$ & 7 (47) & 0.231 \\
\hline Beta-blockers, $n(\%)$ & $16(64)$ & $7(70)$ & $10(67)$ & 0.222 \\
\hline ACE-inhibitors/ARB, $n(\%)$ & $12(48)$ & $6(60)$ & $7(47)$ & 0.688 \\
\hline Statins, $n(\%)$ & $12(48)$ & $8(80)$ & $12(80)$ & 0.687 \\
\hline
\end{tabular}


CAD, metabolic disease or chronic illness $(n=25)$. Baseline clinical features of CTR, CAD-DM and CAD+DM patients are presented in Table 1 . There were no significant differences between three groups with regards to age, gender, BMI, presence of cardiovascular risk factors and medication. $\mathrm{CAD}+\mathrm{DM}$ patients exhibited higher fasting glucose level compared to CTR $(P=0.019)$ and compared to CAD-DM group $(P=0.048)$.

Monocyte isolation and migration

Blood samples $(100 \mathrm{ml})$ were collected from all subjects. Monocytes were isolated by Percoll gradient centrifugation based on a previously described protocol [40]. The purity of isolated monocytes was $\geq 90 \%$ as determined by flow cytometry. Monocytes were subjected to chemotaxis assay using the modified Boyden chamber [2]. Briefly, different concentrations of Shh or Ihh were placed in the bottom well and monocytes were placed in the top well. Polycarbonate membranes with a pore diameter of $5 \mu \mathrm{m}$ (Nuclepore) were used. The chambers were incubated at $37^{\circ} \mathrm{C}$ in the presence of $5 \% \mathrm{CO}_{2}$ for $90 \mathrm{~min}$. Afterwards filters were removed, fixed, stained with Giemsa dye before scraping off cells at the upper side of the filter membrane and five high-power fields were counted for each sample (primary magnification $20 \times$ ). To differentiate between chemotaxis and chemokinesis, checkerboard analysis was performed by placing various dilutions of Shh in both the lower and upper wells of the modified Boyden chamber. To study the effect of different inhibitors on Shh-induced migration, monocytes were pretreated with a specific inhibitor of $\mathrm{Hh}$ signaling, cyclopamine $(\mathrm{CP}, 10 \mu \mathrm{M})$, the PI3K inhibitor, LY294002 $(10 \mu \mathrm{M})$, or a specific inhibitor of $\mathrm{G} \alpha_{\mathrm{i} / \mathrm{o}}$, pertussis toxin (PTX, $100 \mathrm{ng} / \mathrm{ml}$ ) for $15 \mathrm{~min}$ before the chemotaxis assay.

\section{RT-PCR analysis}

Total RNA from monocytes or HUVEC (used as a control) was isolated using RNeasy Protect Mini Kit from QIAGEN. For reverse transcription, $1 \mu \mathrm{g}$ of total RNA was converted into cDNA by AMV reverse transcriptase at $37^{\circ} \mathrm{C}$ for $1 \mathrm{~h}$ in a $20 \mu \mathrm{l} \mathrm{RT}$ reaction. All the primers used in this study and PCR conditions are listed in Table 2.

Flow cytometry analysis

Expression of Ptc on leukocytes was analyzed by flow cytometry. Leukocytes were stained with anti-Ptc primary antibodies (Santa Cruz Biotechnology). Double staining with CD14-FITC (Becton Dickinson) and Ptc/anti-goat-PE antibody was performed to confirm the expression of both proteins on monocytes. The analysis was carried out on a FACSCalibur flow cytometer using the CellQuest software (Becton Dickinson).

Table 2 Primers and conditions used for RT-PCR

\begin{tabular}{|c|c|c|c|}
\hline Gene & Sequence $\left(5^{\prime}-3^{\prime}\right)$ & $\begin{array}{l}\text { Annealing temperature } \\
\text { and cycle number }\end{array}$ & Fragment size (bp) \\
\hline Shh & $\begin{array}{l}\text { FW: ACT GGG TGT ACT ACG AGT CCA AGG } \\
\text { RV: AAA GTG AGG AAG TCG CTG TAG AGC }\end{array}$ & $63^{\circ} \mathrm{C}, 50$ cycles & 211 \\
\hline Ihh & $\begin{array}{l}\text { FW: CTA CGC CCC GCT CAC AAA G } \\
\text { RV: GGC AGA GGA GAT GGC AGG AG }\end{array}$ & $60^{\circ} \mathrm{C}, 30$ cycles & 376 \\
\hline Dhh & $\begin{array}{l}\text { FW: ACCAATCTACTGCCCCTGTG } \\
\text { RV: GTTGTAGTTGGGCACGAGGT }\end{array}$ & $62^{\circ} \mathrm{C}, 30$ cycles & 246 \\
\hline Smo & $\begin{array}{l}\text { FW: CAG GAC ATG CAC AGC TAC ATC G } \\
\text { RV: CCA CAA AGA AGC ACG CAT TGA C }\end{array}$ & $65^{\circ} \mathrm{C}, 30$ cycles & 380 \\
\hline Ptc & $\begin{array}{l}\text { FW: CCA TGT TCC AGT TAA TGA CTC } \\
\text { RV: ACA TCA TCC ACA CCA ACA }\end{array}$ & $55^{\circ} \mathrm{C}, 30$ cycles & 462 \\
\hline SUFU & $\begin{array}{l}\text { FW: CCT CCA GAT CGT TGG TGT CT } \\
\text { RV: CTG TCT CGA TGC CTT TGT CA }\end{array}$ & $55^{\circ} \mathrm{C}, 30$ cycles & 195 \\
\hline Gli-1 & $\begin{array}{l}\text { FW: GGG ATG ATC CCA CAT CCT CAG TC } \\
\text { RV: CTG GAG CAG CCC CCC CAG T }\end{array}$ & $60^{\circ} \mathrm{C}, 50$ cycles & 386 \\
\hline Gli-2 & $\begin{array}{l}\text { FW: ACC GCT GCT CAA AGA GAA TG } \\
\text { RV: CCC ACT GCC ACT GAA GTT TTC C }\end{array}$ & $64^{\circ} \mathrm{C}, 50$ cycles & 507 \\
\hline Gli3 & $\begin{array}{l}\text { FW: CCT CAA AGC GGG CCG CCT GC } \\
\text { RV: CAG GTT GTT GTT GGA CTG TGT GC }\end{array}$ & $64^{\circ} \mathrm{C}, 50$ cycles & 406 \\
\hline
\end{tabular}


Immunohistochemistry

Cross sections of human aortic atherosclerotic plaque were deparaffinized, dehydrated, and permeabilized with $0.05 \%$ Tween in citrate buffer, and then blocked with normal horse serum. Further, they were incubated with primary polyclonal antibodies for Ptc (1:25, goat polyclonals; Santa Cruz Biotechnology Inc) or CD68 (1:100, mouse monoclonal; DakoCytomation). A biotinylated horse anti-mouse and anti-goat $\operatorname{IgG}(1: 1,000)$ was incubated followed by incubation with streptavidin/HRP antibodies and visualized with AEC staining solution. Consecutive sections were stained and the results of Ptc staining and CD68 staining were merged for demonstration of coexpression. The negative controls included substitution of primary antiserum for PBS.

\section{Statistical analysis}

Statistical analysis was performed with SPSS12.0.1 statistical software. Categorical variables are presented as percentage of patients and compared by Fisher's exact test. Data are presented as the mean \pm standard deviation (SD). In addition, the medians (in the figure: median as line, 25th-75th percentiles as box, 5th-95th percentiles as whiskers) are given in case of non-normally distributed results. CTR, CAD-DM and $\mathrm{CAD}+\mathrm{DM}$ patients were compared using a Mann-Whitney $U$ test with Bonferroni correction. Values of $P<0.05$ were considered statistically significant.

\section{Results}

Human peripheral monocytes express components of Hh signaling

Initially, we examined human monocytes for the expression of components involved in Hh signaling including the ligands Shh, Dhh and Ihh, the receptor Ptc, co-receptor Smoothened (Smo), hedgehog interacting protein (Hip), suppressor of Fused (SUFU), transcription factors Gli 1, 2 and 3. We carried out RT-PCR on RNAs prepared from isolated human peripheral monocytes. RNA from HUVEC was used as a positive control. We confirmed the expression of Ihh, Dhh, Ptc, Smo, SUFU and Gli3 genes on monocytes, but could not detect the expression of Shh, Hip, Gli1 and Gli2 (Fig. 1a).

To confirm the surface expression of $\mathrm{Hh}$ receptor Ptc protein, flow cytometric analysis was performed. Double staining of the monocyte fraction with the monocyte marker CD14 and Ptc antibodies demonstrated that $95 \%$ of the monocytes were positive for Ptc (Fig. 1b). These results
A
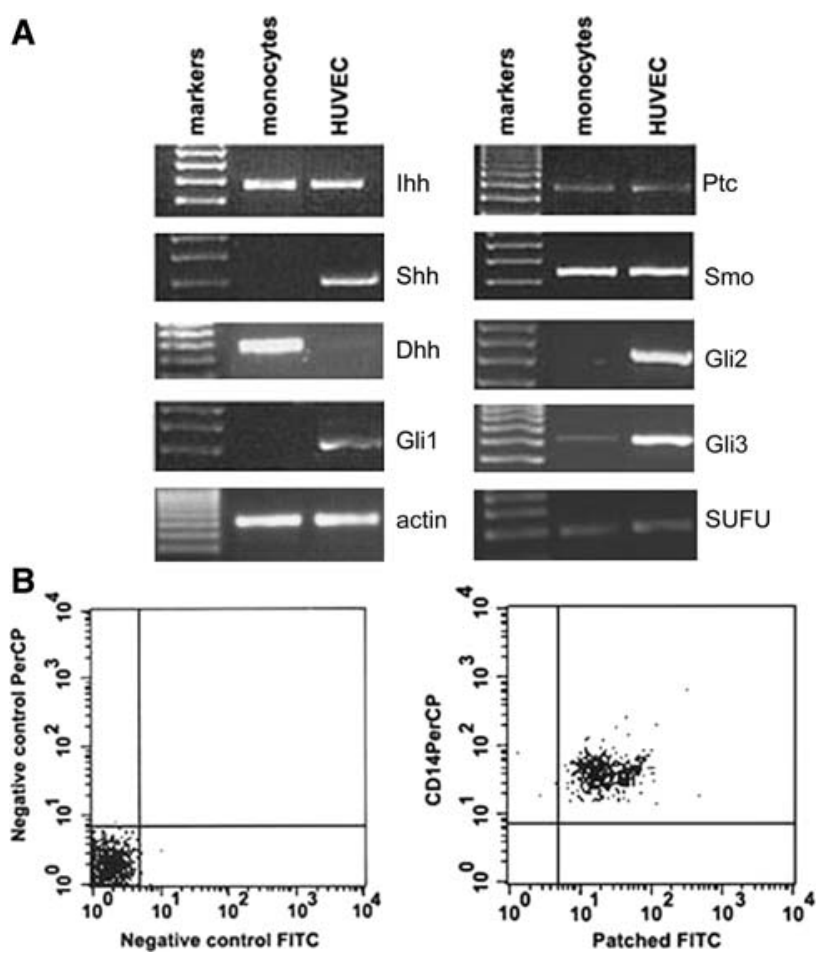

Fig. 1 Expression of Hedgehog signaling components in human monocytes. a RT-PCR analysis of the Shh, Ihh, Dhh, Smo, Ptc, SUFU, Hip, Gli1, Gli2, Gli3, and actin gene expression on human peripheral monocytes and HUVEC (used as a positive control). The results are representative of three independent experiments. b Flow cytometric analysis of Ptc expression on monocytes. Left panel Isotype (negative) control. Right panel Purified monocytes were double-stained with anti-Ptc antibodies and CD14 antibodies as a marker for monocytes

suggest that monocytes can be susceptible to Hh protein stimulation.

Chemotactic properties of Shh

Monocytes isolated from the blood of control subjects were assessed for their ability to migrate to Shh. Shh-induced monocyte chemotaxis with a bell-shaped dose-response curve, whereby stimulation with $0.01 \mu \mathrm{g} / \mathrm{ml}$ Shh stimulated migration to $123.8 \pm 34 \%(P=0.622)$, stimulation with $0.1 \mu \mathrm{g} / \mathrm{ml}$ Shh led to $132.4 \pm 26 \%(P=0.093)$, while stimulation with $1 \mu \mathrm{g} / \mathrm{ml}$ resulted in $172.5 \pm 90 \%$ of baseline $(P<0.005)$, and $2.5 \mu \mathrm{g} / \mathrm{ml}$ Shh in $153.1 \pm 60 \%$ $(P=0.006)$ (Fig. 2a, c). Based on these results, we used $1 \mu \mathrm{g} / \mathrm{ml}$ Shh for all further experiments presented. Similar results were observed when Ihh was used to induce monocyte migration (Fig. 2B). However, the optimal concentration for Ihh was $2.5 \mu \mathrm{g} / \mathrm{ml}$. In the checkerboard control experiment, when Shh was added to both upper and lower wells, monocyte chemotaxis was not observed (Fig. 2a). These data indicate that a concentration gradient of Shh is required for monocyte chemotaxis. 
Fig. 2 Both Shh (a) and Ihh (b) induce migration of human monocytes ex vivo in a concentration-dependent fashion. Monocytes were isolated from peripheral blood samples $(n=25)$ and the chemotactic response was measured using a modified Boyden chamber. Five highpower fields were counted for each sample (primary magnification $\times 20$ ). Statistical significance was evaluated using the unpaired Student's $t$ test. The median values are plotted on the graphs. * $P \leq 0.005$. c Monocyte migration in the presence (right) or absence (left) of Shh $(1 \mu \mathrm{g}$ / $\mathrm{ml})$. The representative photograph of the stained filter; monocytes are detected on the lower surface of the filter following migration through the pores
A

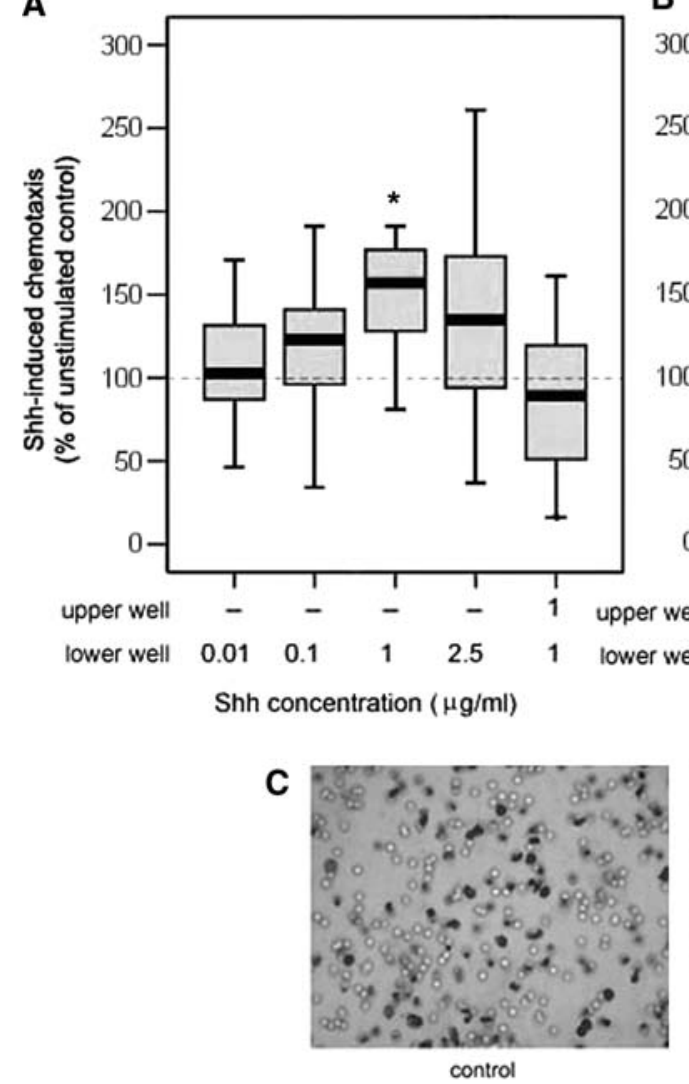

B
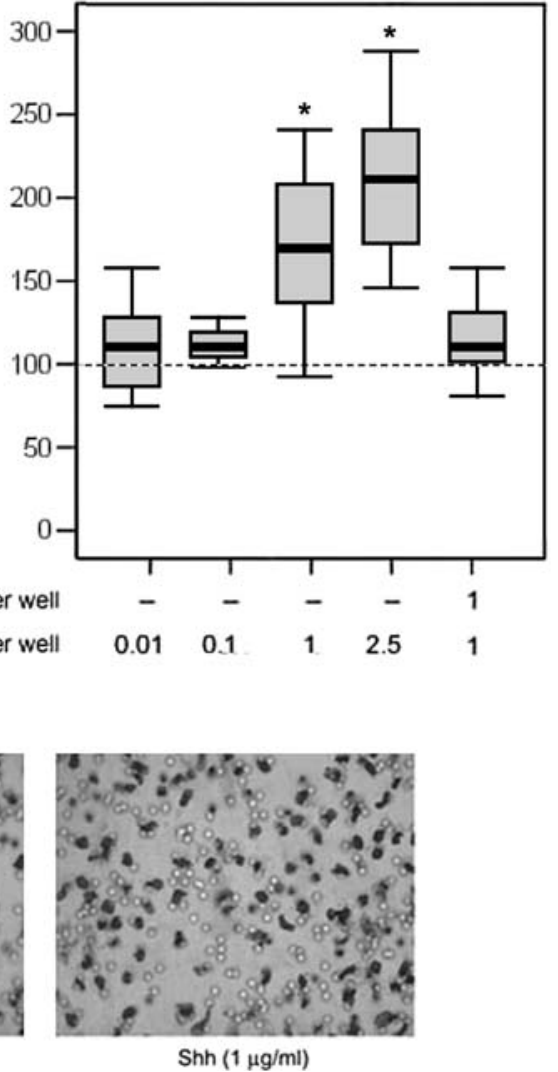

To check the specificity of Shh-induced chemotaxis, we pretreated isolated monocytes with $\mathrm{CP}$, a selective inhibitor of Hh signaling. The steroidal alkaloid $\mathrm{CP}$ specifically inhibits the Hh pathway by direct binding to Smo and induces a conformational shift leading to Smo inactivation [8]. This pretreatment of monocytes had no effect on chemokinesis. However, CP completely inhibited Shhinduced chemotaxis (Fig. 3a). CP did not abrogate monocyte chemotaxis induced by MCP-1 (data not shown). These results indicate that the chemotactic activity of Shh is specific and dependent on Smo activity.

\section{Requirement of G-proteins and PI3 K for Shh-induced} chemotaxis of monocytes

Intracellular chemokine receptor signaling depends on coupling to heterotrimeric G-proteins, usually of the Gitype [19]. To assess whether Shh-induced chemotaxis is mediated by Gi proteins, we pretreated monocytes with pertussis toxin (PTX), a specific inhibitor of $\mathrm{G} \alpha \mathrm{i} / \mathrm{o}$, for $15 \mathrm{~min}$ and stimulated with an optimized concentration of Shh $(1 \mu \mathrm{g} / \mathrm{ml})$. Pretreatment with PTX did not affect chemokinesis $(89 \pm 22 \%, P=0.974)$; however, Shh-induced chemotaxis of monocytes $(165 \pm 25 \%)$ was impaired by PTX to $62.1 \pm 30 \%(P<0.001$, Fig. $3 b)$. These data suggest that Shh-mediated chemotaxis requires signaling via the activation of $\mathrm{G} \alpha \mathrm{i}$.

The binding of a chemoattractant to its receptor leads to an increased activation of PI3K and cell polarization [34]. Recent studies reported that Shh also regulates some processes through the PI3K/Akt pathway $[17,31]$. To investigate the role of the PI3K pathway in Shh-induced migration, we pretreated monocytes with the specific PI3K inhibitor LY294002 for 15 min prior to the chemotaxis assay. LY294002 inhibited both chemokinesis and chemotaxis induced by Shh (Fig. 3c). Chemokinesis was reduced from 100 to $52 \pm 26 \%(P=0.001)$, while Shhinduced chemotaxis was significantly decreased from $165.7 \pm 16$ to $35 \pm 13 \%(P<0.005)$. Overall, our data suggest that Shh-mediated chemotaxis of monocytes involves PI3K and Gi proteins.

Diabetes mellitus type 2, but not CAD, negatively affects Shh-induced migration of human peripheral monocytes

Abnormalities in monocyte function may be responsible for impaired collateral growth in certain patient subsets [10]. It has been demonstrated that CAD patients with DM have a reduced ability to develop collateral blood vessels 
Fig. 3 a Cyclopamine $(C P)$ inhibits Shh-induced monocyte chemotaxis. Monocytes were pretreated with $\mathrm{CP}(10 \mu \mathrm{M})$ for $15 \mathrm{~min}$ and chemotactic response to Shh $(1 \mu \mathrm{g} / \mathrm{ml})$ was measured using the modified Boyden chamber. Statistical significance was evaluated using the unpaired Student's $t$ test. The median values are plotted on the graphs; * $P<0.005, n=11$. Both $\mathrm{G}_{\mathrm{i}}$ inhibitor PTX (100 ng/ml, b) and PI3K inhibitor LY294002 $(10 \mu \mathrm{M}, \mathbf{c})$ block Shh-induced $(1 \mu \mathrm{g} / \mathrm{ml})$ chemotaxis of peripheral monocytes. The median values are plotted on the graphs; * $P<0.005, n=11$

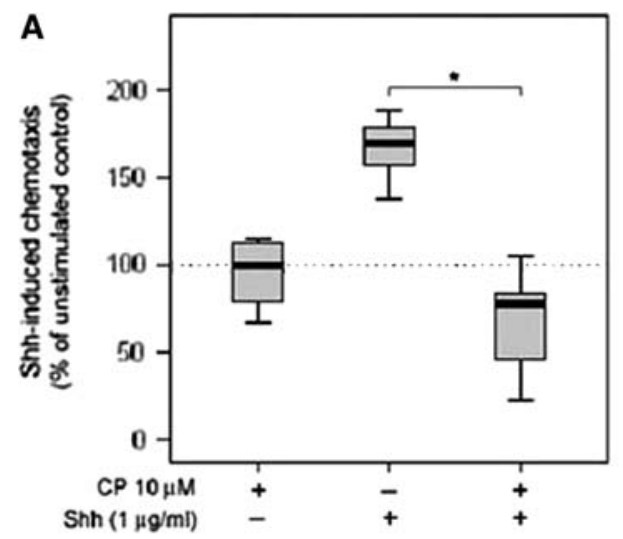

B

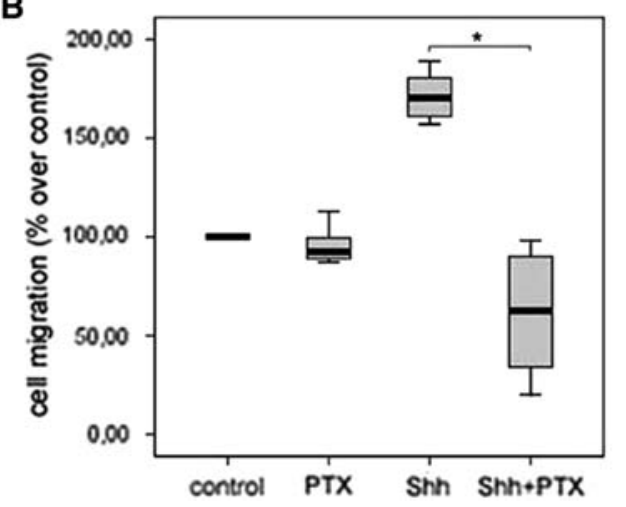

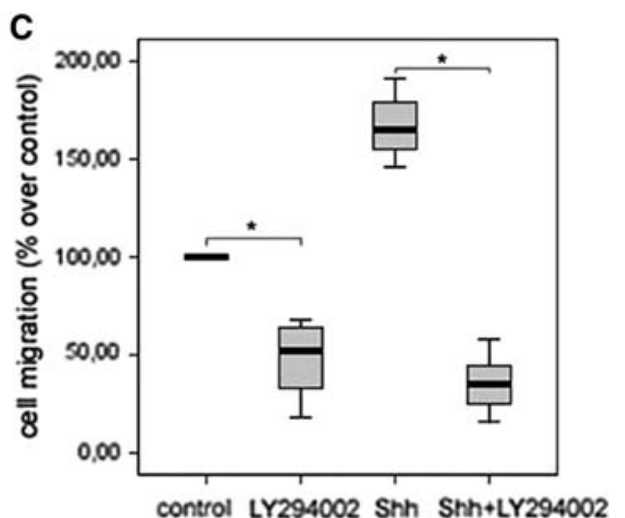

[42]. To check whether the Hh signaling pathway is affected by CAD and DM, we compared the migratory response to Shh of monocytes isolated from CTR, CAD-DM and CAD+DM patients.

Shh $(1 \mu \mathrm{g} / \mathrm{ml})$ did stimulate migration of monocytes from CAD-DM patients. However, the stimulation of migration was lower in CAD-DM compare to CTR $(134 \pm 44$ vs. $172.5 \pm 90 \%, P=0.354)$. In diabetic patients (CAD+DM) Sh failed to induce monocyte migration $(94.3 \pm 27$ vs. CTR, $P<0.001$ and vs. CAD-DM, $P=0.033$; Fig. 4a).

The chronic inflammation associated with DM could affect the expression of the Hh receptor Ptc on monocytes, which might explain the altered chemotactic response in DM. The RT-PCR-based analysis of Ptc expression on monocytes from CTR, CAD-DM and CAD+DM patients revealed that Ptc expression was upregulated in both CAD-DM and CAD+DM (Fig. 4b). The fold of increase was 5.4-fold for CAD-DM patients $(P=0.045)$ and 11 -fold for CAD+DM $(P=0.004)$. In contrast, there were no statistically significant differences in expression of Ihh (Fig. 4c), Dhh, Smo, Gli3, Hip and SUFU mRNA (data not shown). Thus, alterations of $\mathrm{Hh}$ signaling in CAD-DM and $\mathrm{CAD}+\mathrm{DM}$ monocytes could only be observed at the level of the receptor Ptc.

A high interindividual variability of Ptc expression in monocytes from CAD-DM patients was noticed.
Therefore, we checked the correlation of monocyte migration with Ptc expression level for these patients. The results demonstrated the tendency that monocytes showing reduced migration express higher level of Ptc. However, this correlation was not statistically significant.

Upregulation of the receptor Ptc is a direct indication of $\mathrm{Hh}$ signaling activation, since it is a Hh target gene. Gli1 and Hip1 are two other Hh target genes. To confirm the possible activation of $\mathrm{Hh}$ signaling in monocytes from diabetic patients, we analyzed Gli1 and Hip1 mRNA expression on monocytes from different patient groups. Neither Gli1 nor Hip1 mRNA expression in monocytes from different patient groups was detected (data not shown). Thus, our novel data indicate significant alterations of the Hh signaling primarily at the level of receptor Ptc.

The receptor Ptc colocalizes with macrophages in human atherosclerotic plaques

Diabetes mellitus is often associated with accelerated atherosclerosis, which is critically mediated by monocytes/ macrophages. We performed staining with specific Ptc antibodies and CD68 antibodies to check whether macrophages in atherosclerotic lesion express Ptc. Our data clearly demonstrate the colocalization of receptor Ptc with CD68, a marker for macrophages (Fig. 5, merge). Non- 

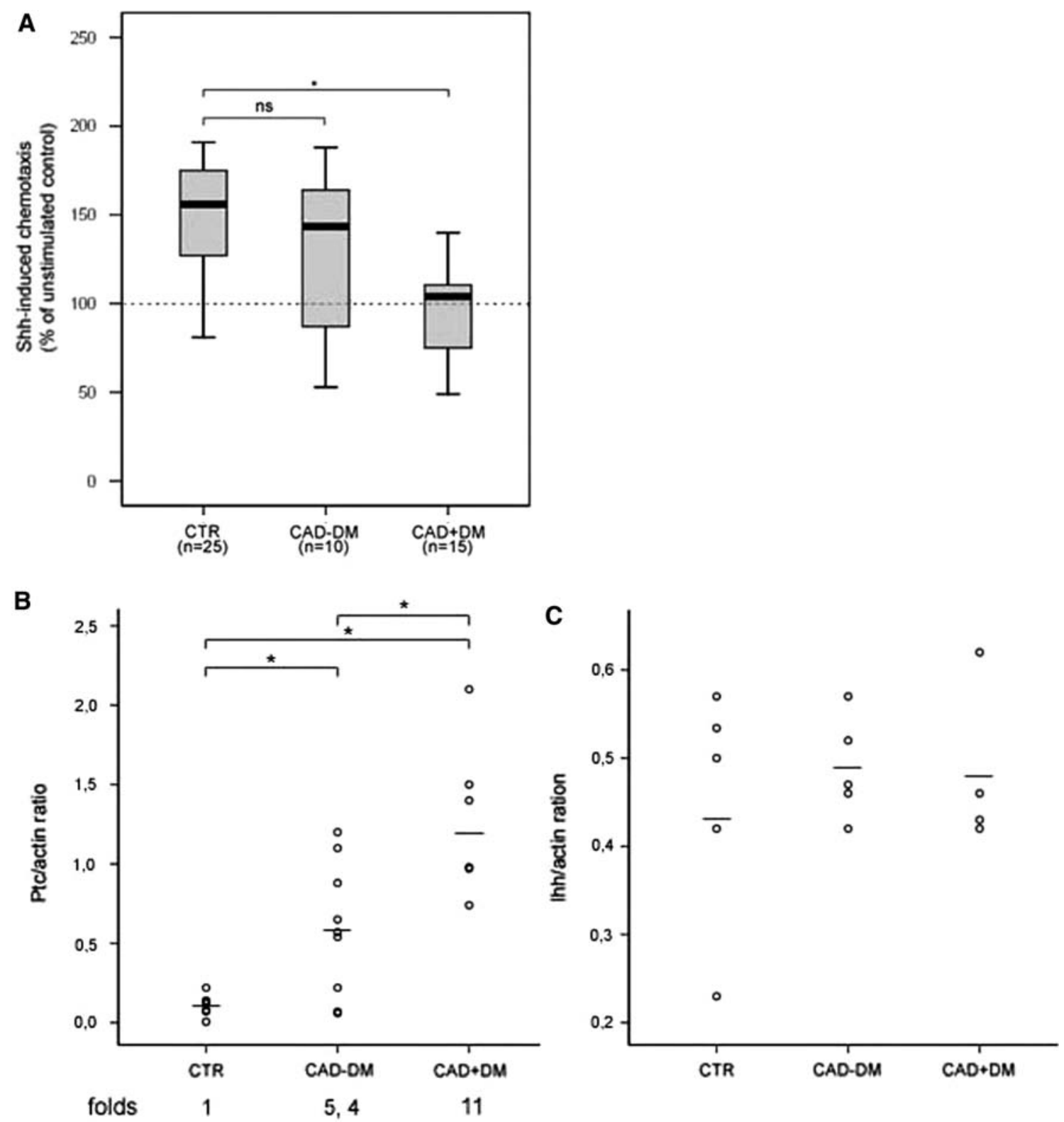

Fig. 4 a Shh-induced $(1 \mu \mathrm{g} / \mathrm{ml})$ chemotaxis of monocytes isolated from CTR, CAD-DM or CAD+DM patients. The median values are plotted; ns; nonsignificant versus unstimulated control. The median (line), 25th and 75th percentiles (box), 5th and 95th percentiles (whiskers) are presented. $* P<0.005$. The level of Ptc (b), and Ihh (c) gene expression on monocytes isolated from CTR, CAD-DM and

immune $\operatorname{IgG}$ did not show any positive staining (data not shown).

\section{Discussion}

In this study, we present data supporting a role for Shh/Ihh in stimulation of monocyte chemotaxis. We have not used Dhh for our experiments, because up to now there is no
CAD+DM patients. RNA isolated from monocytes was subjected to RT-PCR. $\beta$-actin cDNA product served as internal standard to normalize Ptc and Ihh. Signal intensity of Ptc and Ihh mRNA bands was quantified by densitometry and compared with the internal standard $\beta$-actin

evidence that Dhh is expressed in vascular endothelial cell or vascular smooth muscle cells. Our data demonstrate that both Shh and Ihh stimulate monocyte chemotaxis at the optimal concentration for Shh $1 \mu \mathrm{g} / \mathrm{ml}$ and for Ihh $2.5 \mu \mathrm{g} /$ ml. Chemotaxis induced by Shh was specific and Smodependent. Moreover, Shh activates classical intracellular signal transduction pathways related to cellular migration such as G-protein-coupled specific receptor pathways or PI3K. 
Fig. 5 Expression of Ptc in an advanced, stable human aortic atherosclerotic lesion. Immunohistological analysis demonstrates that approximately $80 \%$ of macrophages were positive for both Ptc and CD68 (merge). Brown color indicates positivity. Sections were counterstained with hematoxylin. Magnification for upper panels is $\times 10$ and for lower panels (magnified inserts) is $\times 40$

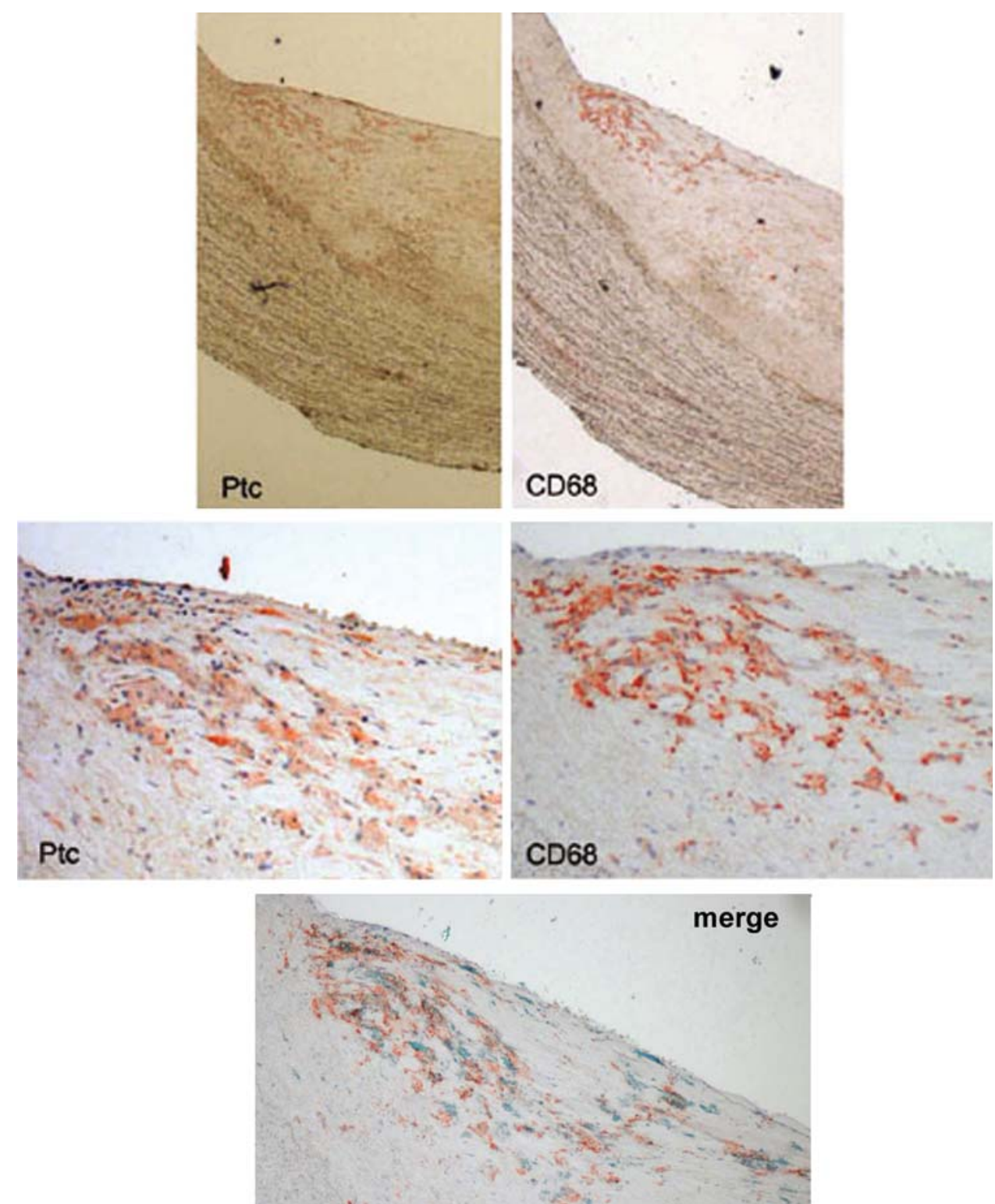

The Shh concentration, which stimulates a maximum effect, is rather high in comparison with other known chemoattractants such as MCP-1, MIPs and fractalkine [25]. This may be explained as follows: Hh proteins undergo two posttranslational processing events that result in the covalent addition of cholesterol at the C-terminus [30] and a long-chain fatty acid on the N-terminal cysteine [34]. In addition to tethering the protein to the surface of the cell in which it is synthesized, lipid modification greatly stimulates biological activity of the protein [28, 37]. Recombinant Shh used in these experiments was expressed and purified from $E$. coli, where it does not undergo those hydrophobic modifications. Recombinant Shh is therefore less potent that natural modified proteins [38].

Our current study was not designed to identify the physiological source of Shh that could influence monocyte migration. Nevertheless, it has already been demonstrated that vascular endothelial [4] and smooth muscle cells [25] express Shh. It is thus conceivable that Shh expressed in these cells may attract monocytes into a vessel. Moreover, altered expression of Shh has been reported in a variety of different pathological conditions such as tumorgenesis [14] and ischemic injury [21]. Expression of both Shh and Ptc was increased in cardiac ischemia. Shh expression was upregulated at the sites of inflammation [29] and repair [41].

Recent reports have indicated that abnormalities in monocyte function may be one of the factors responsible for reduced vessel growth and vascular complications in certain patient groups [39]. Monocytes from diabetic patients show a migration defect [40], reduced phagocytosis [20, 26] and increased adhesion to endothelial cells 
[9]. The present study demonstrates that monocytes from diabetic patients do not respond to Shh at the most efficient concentration in CTR, i.e. $1 \mu \mathrm{g} / \mathrm{ml}$. This impaired chemotactic response was associated with a 11-fold increase of Ptc mRNA expression in diabetic monocytes. The increase of Ptc expression could be also observed for some CADDM patients; however, the difference in expression was not statistically significant in comparison to control subjects (3 patients from 10 had higher level of Ptc expression compared to control). However, there was no significant difference in mRNA expression between different groups for ligands Ihh and Dhh and downstream Hh signaling components Smo and SUFU. Previously, impaired chemotactic response of monocytes associated with increased surface expression of receptors was observed for patients with DM type 1 [5]. Similar effect was observed for blood monocytes from epithelial ovarian cancer. Notwithstanding the increased levels of CCR2 and CCR5 detected on ascitic monocytes, in comparison to that of normal donors, migration response to their ligand RANTES was impaired [16].

Diabetes mellitus type 2 is often associated with obesity. It has been reported that the Hh signaling pathway was less active in obese compared to lean mice. Two models have been tested, mice invalidated in leptine (ob/ob) and highfat diet induced obesity. So far all experiments leading to a stimulation of Hh signaling in vivo result in an enlarged body mass and conversely, an inhibition of the pathway prevents weight gain [11]. We did not observe significant differences between CAD-DM and CAD+DM with regards to BMI. Therefore, it is unlikely that an excess of adipose mass, which characterizes obesity and is often associated with diabetes, may play a role in disregulation of Hh pathway.

Moreover, diabetes mellitus is also accompanied by a systemic low-grade inflammation and it is an important factor in accelerating atherosclerosis. It has been reported that LPS-induced Ptc expression in macrophages after $18 \mathrm{~h}$ in culture [41]. Thus, low-grade inflammation could upregulate expression of Ptc on circulating monocytes of diabetes patients. In addition, it has been previously shown in Drosophila that to achieve maximal pathway activity, large excess (more than 50-fold) of Smo over Ptc is required [36]. If similar regulation of $\mathrm{Hh}$ signaling applies to the human system, the strong upregulation of Ptc and preserved expression level of Smo in diabetic patients could explain the observed defect in Hh signaling.

Monocytes/macrophages are recognized as one of the principal cell types in the pathology of atherosclerosis [43, 44]. Accumulating evidence suggests that the Hh pathway is involved in peripheral immunity and tissue remodeling $[21,23]$. Expression of Shh and Ptc is upregulated in small bowel allografts undergoing chronic rejection. Systemic treatment with a neutralizing anti-Shh antibody reduced tissue remodeling, fibrosis and vascular occlusion of the intestinal grafts [7]. The cells that expressed Ptc in the intestinal grafts undergoing chronic rejection were mainly macrophages. In a recent study using an $\mathrm{ApoE}^{-/-}$-based mouse model of atherosclerosis, inhibition of Shh using specific antibodies resulted in a pro-atherosclerotic phenotype secondary to enhanced lipid uptake in macrophages [3]. Our novel data do support the idea that inhibition of Shh may be pro-atherogenic. Macrophages in human atherosclerotic plaques express high levels of receptor Ptc. The diabetes-related inhibition of macrophages may prevent their clearance from atherosclerotic plaques. This could be a novel molecular mechanism promoting atherosclerosis; however, its functional relevance and extent in the pathogenesis of human atherosclerosis remains to be determined.

Thus, our data represent the first example of an endogenous metabolic abnormality, namely DM, which is associated with a functional inhibition of the Hh signaling pathway. Likewise, this impaired monocyte function is likely to be associated with impaired arteriogenesis and impaired wound healing [35, 39]. Identification of novel signal transduction pathways regulating monocyte chemotaxis can indicate unique targets for preventive therapies for treatment of chronic inflammatory diseases.

Acknowledgments We wish to acknowledge the support from Moniek Baggen in patient recruitment. This study was supported in part by grant VEGF therapies (QLRT-2001-01955) from the European Commission, and by the Cardiovascular Research Institute Maastricht (CARIM).

\section{Conflict of interest statement None}

Open Access This article is distributed under the terms of the Creative Commons Attribution Noncommercial License which permits any noncommercial use, distribution, and reproduction in any medium, provided the original author(s) and source are credited.

\section{References}

1. Asai J, Takenaka H, Kusano K, Ii M, Luedemann C, Curry C, Eaton E, Iwakura A, Tsutsumi Y, Hamada H, Kishimoto S, Thorne T, Kishore R, Losordo D (2006) Topical sonic hedgehog gene therapy accelerates wound healing in diabetes by enhancing endothelial progenitor cell-mediated microvascular remodeling. Circulation 113:2413-2424

2. Barleon B, Sozzani S, Zhou D, Weich H, Mantovani A, Marmé D (1996) Migration of human monocytes in response to vascular endothelial growth factor (VEGF) is mediated via the VEGF receptor flt-1. Blood 87:3336-3343

3. Beckers L, Heeneman S, Wang L, Burkly L, Rousch M, Davidson N, Gijbels M, de Winther M, Daemen M, Lutgens E (2007) Disruption of hedgehog signalling in ApoE-/- mice reduces plasma lipid levels, but increases atherosclerosis due to enhanced lipid uptake by macrophages. J Pathol 212:420-428 
4. Bhardwaj G, Murdoch B, Wu D, Baker D, Williams K, Chadwick K, Ling L, Karanu F, Bhatia M (2001) Sonic hedgehog induces the proliferation of primitive human hematopoietic cells via BMP regulation. Nat Immunol 2:172-180

5. Bouma G, Coppens J, Lam-Tse W, Luini W, Sintnicolaas K, Levering W, Sozzani S, Drexhage H, Versnel M (2005) An increased MRP8/14 expression and adhesion, but a decreased migration towards proinflammatory chemokines of type 1 diabetes monocytes. Clin Exp Immunol 141:509-517

6. Charron F, Stein E, Jeong J, McMahon AP, Tessier-Lavigne M (2003) The morphogen sonic hedgehog is an axonal chemoattractant that collaborates with netrin-1 in midline axon guidance. Cell 113:11-23

7. Chen Y, Li X, Tian L, Lui V, Dallman M, Lamb J, Tam P (2007) Inhibition of sonic hedgehog signaling reduces chronic rejection and prolongs allograft survival in a rat orthotopic small bowel transplantation model. Transplantation 83:1351-1357

8. Chen J, Taipale J, Cooper M, Beachy P (2002) Inhibition of Hedgehog signaling by direct binding of cyclopamine to Smoothened. Genes Dev 16:2743-2748

9. Cipolletta C, Ryan K, Hanna E, Trimble E (2005) Activation of peripheral blood CD14+ monocytes occurs in diabetes. Diabetes 549:2779-2786

10. Cohen M (2003) The hedgehog signaling network. Am J Med Genetics 123:5-28

11. Cousin W, Fontaine C, Dani C, Peraldi P (2007) Hedgehog and adipogenesis: fat and fiction. Biochimie 89:1447-1453

12. Deshpande G, Swanhart L, Chiang P, Schedl P (2001) Hedgehog signaling in germ cell migration. Cell 106:759-769

13. Dyer M, Farrington S, Mohn D, Munday J, Baron M (2001) Indian hedgehog activates hematopoiesis and vasculogenesis and can respecify prospective neurectodermal cell fate in the mouse embryo. Development 128:1717-1730

14. Fan L, Pepicelli C, Dibble C, Catbagan W, Zarycki J, Laciak R, Gipp J, Shaw A, Lamm M, Munoz A, Lipinski R, Thrasher J, Bushman W (2004) Hedgehog signaling promotes prostate xenograft tumor growth. Endocrinology 145:3961-3970

15. Frantz S, Vincent K, Feron O, Kelly R (2005) Innate immunity and angiogenesis. Circ Res 96:15-26

16. Freedman R, Ma Q, Wang E, Gallardo S, Gordon I, Shin J, Jin P, Stroncek D, Marincola F (2008) Migration deficit in monocytemacrophages in human ovarian cancer. Cancer Immunol Immunother 57:635-645

17. Fu J, Liu W, Zhou J, Sun H, Xu H, Luo L, Zhang H, Zhou YF (2006) Sonic hedgehog protein promotes bone marrow-derived endothelial progenitor cell proliferation, migration and VEGF production via PI 3-kinase/Akt signaling pathways. Acta Pharmacol Sin 27:685-693

18. Hochman E, Castiel A, Jacob-Hirsch J, Amariglio N, Izraeli S (2006) Molecular pathways regulating pro-migratory effects of Hedgehog signaling. J Biol Chem 281:33860-33870

19. Kamps A, Coffman C (2005) G protein-coupled receptor roles in cell migration and cell death decisions. Ann N Y Acad Sci 1049:17-23

20. Katz S, Klein B, Fishman P, Djaldetti M (1983) Phagocytotic activity on monocytes from diabetic patients. Diabetes Care 6:479-482

21. Kusano K, Pola R, Murayama T, Curry C, Kawamoto A, Iwakura A, Shintani S, Ii M, Asai J, Tkebuchava T, Thorne T, Takenaka H, Aikawa R, Goukassian D, von Samson P, Hamada H, Yoon YS, Silver M, Eaton E, Ma H, Heyd L, Kearney M, Munger W, Porter JA, Kishore R, Losordo DW (2005) Sonic hedgehog myocardial gene therapy: tissue repair through transient reconstitution of embryonic signaling. Nat Med 11:1197-1204

22. Lavine K, White A, Park C, Smith C, Choi K, Long F, Hui C, Ornitz D (2006) Fibroblast growth factor signals regulate a wave of Hedgehog activation that is essential for coronary vascular development. Genes Dev 20:1651-1666

23. Lowrey J, Stewart G, Lindey S, Hoyne G, Dallman M, Howie S, Lamb J (2002) Sonic hedgehog promotes cell cycle progression in activated peripheral $\mathrm{CD} 4(+) \mathrm{T}$ lymphocytes. J Immunol 169:1869-1875

24. Merchán P, Bribián A, Sánchez-Camacho C, Lezameta M, Bovolenta P, de Castro F (2007) Sonic hedgehog promotes the migration and proliferation of optic nerve oligodendrocyte precursors. Mol Cell Neurosci 36:355-368

25. Morrow D, Sweeney C, Birney Y, Guha S, Collins N, Cummins P, Murphy R, Walls D, Redmond E, Cahill P (2007) Biomechanical regulation of hedgehog signaling in vascular smooth muscle cells in vitro and in vivo. Am J Physiol Cell Physiol 292:C488-C496

26. O'Brien B, Huang Y, Geng X, Dutz J, Finegood D (2002) Phagocytosis of apoptotic cells by macrophages from NOD mice is reduced. Diabetes 51:2481-2488

27. Pathi S, Pagan-Westphal S, Baker D, Garber E, Rayhorn P, Bumcrot D, Tabin CJ, Blake Pepinsky R, Williams KP (2001) Comparative biological responses to human Sonic, Indian, and Desert hedgehog. Mech Dev 106:107-117

28. Pepinsky R, Zeng C, Wen D, Rayhorn P, Baker D, Williams K, Bixler S, Ambrose C, Garber E, Miatkowski K, Taylor F, Wang E, Galdes A (1998) Identification of a palmitic acid-modified form of human Sonic hedgehog. J Biol Chem 273:14037-14045

29. Pola R, Ling L, Silver M, Corbley M, Kearney M, Blake Pepinsky R, Shapiro R, Taylor F, Baker D, Asahara T, Isner J (2001) The morphogen Sonic hedgehog is an indirect angiogenic agent upregulating two families of angiogenic growth factors. Nat Med 7:706-711

30. Porter J, Young K, Beachy P (1996) Cholesterol modification of hedgehog signaling proteins in animal development. Science 274:255-259

31. Riobo N, Lu K, Ai X, Haines G, Emerson C (2006) Phosphoinositide 3-kinase and Akt are essential for Sonic hedgehog signaling. Proc Natl Acad Sci USA 103:4505-4510

32. Schaper W, Scholz D (2003) Factors regulating arteriogenesis. Arterioscler Thromb Vasc Biol 23:1143-1151

33. Shinozaki S, Ohnishi H, Hama K, Kita H, Yamamoto H, Osawa H, Sato K, Tamada K, Mashima H, Sugano K (2008) Indian hedgehog promotes the migration of rat activated pancreatic stellate cells by increasing membrane type- 1 matrix metalloproteinase on the plasma membrane. J Cell Physiol 216:38-46

34. Stephens L, Ellson C, Hawkins P (2002) Roles of PI3Ks in leukocyte chemotaxis and phagocytosis. Curr Opin Cell Biol 14:203-213

35. Stewart G, Hoyne G, Ahmad S, Jarman E, Wallace W, Harrison D, Haslett C, Lamb J, Howie S (2003) Expression of the developmental Sonic hedgehog (Shh) signalling pathway is up-regulated in chronic lung fibrosis and the Shh receptor patched 1 is present in circulating T lymphocytes. J Pathol 199:488-495

36. Taipale J, Cooper M, Maiti T, Beachy P (2002) Patched acts catalytically to suppress the activity of Smoothened. Nature 418:892-897

37. Taylor F, Wen D, Garber E, Carmillo A, Baker D, Arduini R, Williams KP, Weinreb PH, Rayhorn P, Hronowski X, Whitty A, Day ES, Boriack-Sjodin A, Shapiro RI, Galdes A, Pepinsky RB (2001) Enhanced potency of human Sonic hedgehog by hydrophobic modification. Biochemistry 40:4359-4371

38. Wakelin S, Forsythe J, Garden O, Howie S (2008) Commercially available recombinant sonic hedgehog up-regulates $\mathrm{Ptc}$ and modulates the cytokine and chemokine expression of human macrophages: an effect mediated by endotoxin contamination? Immunobiology 213:25-38 
39. Waltenberger J (2001) Impaired collateral development in diabetes: potential cellular mechanisms and therapeutic implications. Cardiovasc Res 49:554-560

40. Waltenberger J, Lange J, Kranz A (2000) Vascular endothelial growth factor-A-induced chemotaxis of monocytes is attenuated in patients with diabetes mellitus: a potential predictor for the individual capacity to develop collaterals. Circulation 102:185-190

41. Watkins D, Berman D, Burkholder S, Wang B, Beachy P, Baylin S (2003) Hedgehog signalling within airway epithelial progenitors and in small-cell lung cancer. Nature 422:313-317
42. Werner G, Richartz B, Heinke S, Ferrari M, Figulla H (2003) Impaired acute collateral recruitment as a possible mechanism for increased cardiac adverse events in patients with diabetes mellitus. Eur Heart J 24:1134-1142

43. Zernecke A, Weber C (2005) Inflammatory mediators in atherosclerotic vascular disease. Basic Res Cardiol 100:93-101

44. Zhang C (2008) The role of inflammatory cytokines in endothelial dysfunction. Basic Res Cardiol 103:398-406 